\title{
Modeling of Solar Radiation Using Silicon Solar Module
}

\author{
JoonYong Kim ${ }^{1}$, Seung-Hwan Yang ${ }^{4}$, ChunGu Lee ${ }^{1}$, Young-Joo Kim ${ }^{3}$, \\ Hak-Jin Kim ${ }^{1,2}$, Seong In Cho ${ }^{1,2}$, Joong-Yong Rhee ${ }^{1,2}$ * \\ ${ }^{1}$ Dept. of Biosystems Engineering, Seoul National University, Seoul, Korea, ${ }^{2}$ Research Institute for Agriculture and \\ Life Sciences, Seoul National University, Seoul, Korea, ${ }^{3}$ Environmentally Materials \& Components Center, \\ Korea Institute of Industrial Technology, Jeonju, Korea, ${ }^{4}$ Center for Safety Measurement, \\ Korea Research Institute of Standards and Science, Daejeon, Korea
}

Received: December $8^{\text {th }}, 2011$; Revised: February $13^{\text {th }}, 2012$; Accepted: February $29^{\text {th }}, 2012$

\section{Abstract}

Purpose: Short-circuit current of a solar module that is widely used as a power source for wireless environmental sensors is proportional to solar radiation although there are a lot of factors affecting the short-circuit current. The objective of this study is to develop a model for estimating solar radiation for using the solar module as a power source and an irradiance sensor. Methods: An experiment system collected data on the short-circuit current and environmental factors (ambient temperature, cloud cover and solar radiation) during 65 days. Based on these data, two linear regression models and a non-linear regression model were developed and evaluated. Results: The best model was a linear regression model with short-circuit current, angle of incidence and cloud cover and its overall RMSE(Root Means Square Error) was 66.671 $\mathrm{W} / \mathrm{m}^{2}$. The other linear model (RMSE $69.038 \mathrm{~W} / \mathrm{m}^{2}$ ) was also acceptable when the cloud cover data is not available.

Keywords: Greenhouse, Pyranometer, Regression Model, Solar Module, Wireless Sensor

\section{Introduction}

Modern farmers have been struggling with the production cost and quality of the produce. Since Willits et al. (1980) started to use a micro processor for environment control in greenhouse, various computer and sensor based environment control systems have been developed for those needs.

Solar radiation, which is one of the sensing parameters, has been used to save HVAC (Heating, Ventilating and Air Conditioning) energy and to produce high quality farm products. (Pan et al., 2004) Real time solar radiation is used for $\mathrm{CO}_{2}$ concentration control (Kläringa et al., 2007), supplementary lighting control (Yuehua et al., 2010), while accumulated solar radiation is used for yield prediction (Seshu and Cady, 1983), irrigation system control

\footnotetext{
*Comesponding author: Joong-Yong Rhee

Tel: +82-2-880-4605; Fax: +82-2-885-8027

E-mail: jyr@snu.ac.kr
}

(Roh and Lee, 1996).

Solar radiation was not considered as a sensing parameter until the past few years due to high price of pyranometer. Since Whillier (1964) and J.P. Kerr et al. (1967) tried to develop a pyranometer using a Si solar cell, pyranometers have been integrated compensation devices for better accuracy and independency to spectrum change. Nowaday two types of pyranometer are available in the market. A thermopile pyranometer is very expensive because of its great accuracy and insensitivity to spectrum change. A photodiode pyranometer is sensitive to spectrum change and relatively inexpensive compared to thermopile pyranometer. Accuracy and response time of solar radiation measurment are not of big concern in horticulture, however sensors with affordable price and less accuracy are not available in the market.

Meanwhile the solar power systems have been widely used as a renewable energy source not only in urban but also in rural area. A remote controlled weeder using solar 
module was developed and evaluated (Kim and Jang, 2007). Some environment monitoring systems adopt a solar module for power source of remote sensors. Various wireless sensors with solar power source have been developed and used due to their low cost and long service life (Kim et al., 2008; Sun et al., 2009).

This research was to develop a low cost remote environment monitoring system for farmers. Si solar module was selected as a power source of the temperature, humidity and $\mathrm{CO}_{2}$ sensors as well as a possible radiation sensor. In principle, a solar module can be used as a sensor for solar radiation because a solar module is a set of solar cells. However, other factors affecting on the current of the solar module causes significant errors in measurement. In this paper, behavior of the short-circuit current of Si solar module was theoretically investigated, and a simple form of statistical model for estimating solar radiation was proposed, experiments to test the models were accomplished and the developed models were evaluated to check if the models are acceptable for the horticultural purpose.

\section{Materials and Methods}

\section{Modelling the short-circuit current of a solar cell}

The short-circuit current of a silicon solar cell is directly proportional to the incident solar radiation (Kerr et al., 1967), but it is significantly affected by many factors such as solar angle-of-incidence (AOI), device temperature, tilt orientation, mechanical and optical asymmetries in the instrument, thermal response time, the ratio of the diffuse to direct components of the total irradiance, linearity of response with irradiance level, and the air mass (King and Myers, 1997). El-Shobokshy and Hussein (1993) described the effect of accumulation of dust and particulate matter onto the surface of photovoltaic cells. Parretta et al. (1998) developed four independent models describing four loss effects; reflection and absorption at the front cover of the module, spectrum, intensity of the light and temperature of module.

King (1997) proposed empirical equations for a solar module in an arbitrary operating condition. Eq. (1), which is one of the equations, shows a relationship between short-circuit current, solar radiation, cell temperature, absolute air mass $\left(A M_{a}\right)$ and angle of incidence $(A O I)$.

$$
I_{s c}=\frac{E}{E_{0}} f_{1}\left(A M_{a}\right) f_{2}(A O I)\left\{I_{s c o}+\alpha_{I_{s c}}\left(T_{c}-T_{o}\right)\right\}
$$

where, $I_{s c}$ : short-circuit current of solar module

$E$ : Plane of array solar irradiance using broadband pyranometer measurement corrected for angle of incidence sensitivity $\left(\mathrm{W} / \mathrm{m}^{2}\right)$

$E_{o}$ : Reference "one sun" irradiance in plane of array $\left(1000 \mathrm{~W} / \mathrm{m}^{2}\right)$

$f_{1}\left(A M_{a}\right)$ : Empirically determined function for solar spectral influence

$f_{2}(A O I)$ : Empirically determined function for angle of incidence influence

$A M_{a}$ : Absolute air mass

$A O I$ : Solar angle of incidence on module $\left({ }^{\circ}\right)$

$T_{c} \quad$ : Temperature of cells inside module $\left({ }^{\circ} \mathrm{C}\right)$

$T_{o} \quad$ : Reference temperature for cells in module $\left(25^{\circ} \mathrm{C}\right)$

$I_{s c o} \quad: I_{s c}$ at standard test condition $\left(E_{o}=1000\right.$ $\left.W / m^{2}, T_{c}=25^{\circ} \mathrm{C}, A M_{a}=1.5, A O I=0^{\circ}\right)$

$\alpha_{I_{s c}}: I_{s c}$ temperature coefficient $\left(\mathrm{A} /{ }^{\circ} \mathrm{C}\right)$

King et al. (2003) reported two empirical equations for calculating cell temperature inside the module and temperature of backside of the module using solar radiation and wind speed. In this study, it's assumed the effect of wind speed could be ignored because it is less significant than the effect of temperature or solar radiation and it's not easy to measure wind speed for practical use. Eq. (2) is the re-written empirical equations by ignoring the wind speed effect in the equations proposed by King et al.(2003). The reported range of a and $\Delta T$ are about $2.81 \sim-3.56$ and $0 \sim 13^{\circ} \mathrm{C}$, respectively.

$$
T_{c}=E\left(e^{a}+\frac{\Delta T}{E_{0}}\right)+T_{a}
$$

where, $T_{c}$ : temperature of solar cell $\left({ }^{\circ} \mathrm{C}\right)$

$T_{a}$ : air temperature $\left({ }^{\circ} \mathrm{C}\right)$

E $\quad$ : solar radiation $\left(W / \mathrm{m}^{2}\right)$

$\triangle T$ : temperature difference between back side of module and solar cell at standard radiation $-1000 \mathrm{~W} / \mathrm{m}^{2}\left({ }^{\circ} \mathrm{C}\right)$

a : empirical coefficient

By inserting Eq. (2) into Eq. (1), the short-circuit current of solar module could be modeled as Eq. (3) 


$$
\begin{aligned}
I_{s c} & =\frac{E}{E_{0}} f_{1}\left(A M_{a}\right) f_{2}(A O I)\left\{I_{s c o}+\alpha_{I_{s c}}\left(T_{c}-T_{o}\right)\right\} \\
& =\frac{E}{E_{0}} f_{1}\left(A M_{a}\right) f_{2}(A O I)\left[I_{s c o}+\alpha_{I_{c x}}\left\{E\left(e^{a}+\frac{\Delta T}{E_{0}}\right)+T_{a}-T_{o}\right\}\right]
\end{aligned}
$$

\section{Cloud Cover}

The cloud cover is the fraction of the sky covered by clouds. The KMA (Korea Meterological Administration) announces its hourly value between 0 and 10 by regional groups. It has an inverse relation with solar radiation and several researchers tried to estimate solar radiation using it. Kasten, F. and G. Czeplak (1980) analyzed the dependence of solar radiation on cloud amount and cloud type. Gul et al. (1998) compared CRM (cloud-cover radiation model) and MRM (meteorological radiation model). Yoo et al. (2008) estimated solar radiation using cloud cover.

\section{Experiments and data collection}

A solar module (TSM-10M, Shanghai Topsolar Green Energy Co., LTD., China) consisted of 36 solar cells con-

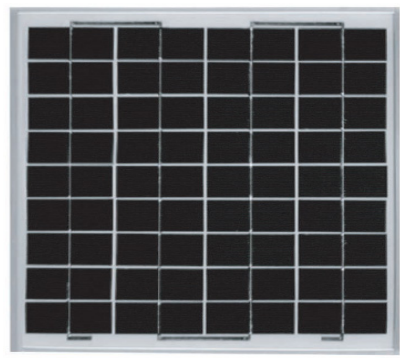

(a) TSM-10M, solar module

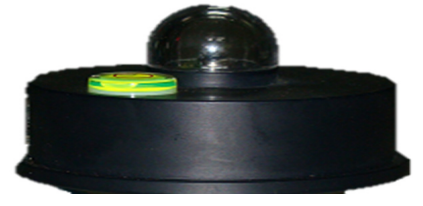

(b) SYE-420M2007PM4, pyranometer nected in series without bypass diode. The short-circuit current coefficient $\left(\alpha_{I_{s c}}\right)$ is $0.05 \% /{ }^{\circ} \mathrm{C}$ and the maximum short-circuit current is $0.67 \mathrm{~A}$ at the standard test condition. A hall effect base linear current sensor (WCS1702, Winson Semiconductor Corp., Taiwan) was used for measuring short-circuit current. The sensitivity is 1.0 $\mathrm{mV} / \mathrm{mA}$ and the internal resistance is $0.24 \Omega$. A pyranometer (SYE-420M2007PM4, ShinYoung Electronics Co,. LTD., Korea) was used for measuring short-circuit current and solar radiation, respectively. The measurable range is $0 \sim 2,000 \mathrm{~W} / \mathrm{m}^{2}$ and the error is less than $\pm 18 \mathrm{~W} / \mathrm{m}^{2}$ at temperature range $-40^{\circ} \mathrm{C} \sim 80^{\circ} \mathrm{C}$.

A software for data collecting was developed in Labview 8.5 (National Instrument, USA) and Mysql 5.1.41 (Oracle, USA) was used as a data storage system. Short- circuit current was measured every second and ambient temperature and solar radiation was collected every minute. A program written in Python programming language (Python Software Foundation, 2.6) was used to get hourly cloud cover data from KMA web site (http:// www.kma. go.kr).

Data on solar radiation and short-circuit current of the solar module were collected from $14^{\text {th }}$ April 2011 to $20^{\text {th }}$ June 2011 at Gyeonggi-do Agricultural Research \& Extension Services. (latitude $37^{\circ} 13^{\prime} 21.27^{\prime \prime} \mathrm{N}$, longitude $127^{\circ}$ 2'30.74"E) AOI at the experimental site was calculated using the following formula. (Nam et al., 2008)

$$
\begin{aligned}
& \delta=\sin ^{-1}\left[\sin 23.45^{\circ} \sin \left\{\frac{360}{370}(d-80)\right\}\right. \\
& A O I=90^{\circ}-\sin ^{-1}[\sin \delta \sin \phi+\cos \delta \cos \phi \cos t]
\end{aligned}
$$

where, $\delta:$ declination

$$
\varphi \text { : latitude }
$$

Figure 1. Experimental devices.

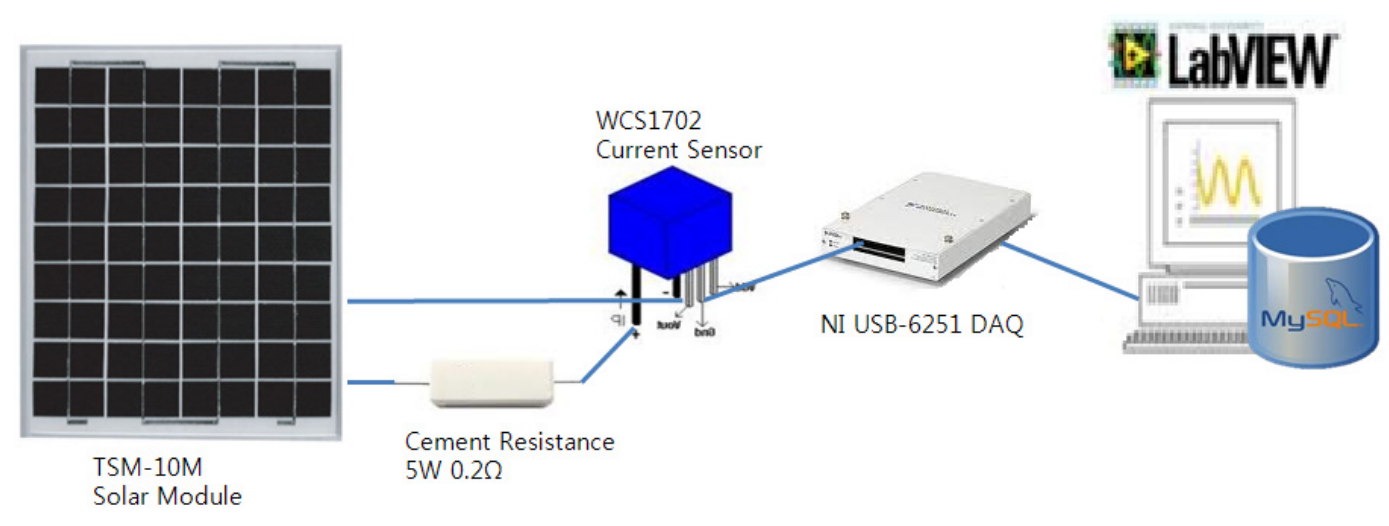

Figure 2. Structure of data acquisition system. 


$$
\begin{aligned}
& d \text { : day of year } \\
& t \quad \text { : angle of time }
\end{aligned}
$$

The absolute airmass $\left(A M_{a}\right)$ was calculated using Eq. (6) proposed by Kasten and Young (1989).

$$
A M_{a} \approx \frac{e^{(-0.0001184 \circ h)}}{\left[\cos \left(Z_{s}\right)+0.5057\left(96.080-Z_{s}\right)^{-1.634}\right]}
$$

where, $A M_{a}$ : absolute airmass

$$
Z_{s} \quad \text { : solar zenith angle }
$$$$
\text { h : site altitude }
$$

\section{Development of regression models and evaluation}

Linear and non-linear models for the solar radiation were considered. For linear regression models, $I_{S C}, T_{a}$, $\cos (A O I)$ were selected as dependent variables because these are known to have linear relation with solar radiation. (Kerr et al., 1967; King et al., 2003). And $I_{S C} \times T_{a}$ was considered because short-circuit current and temperature of solar cell has an interaction. The last dependent variable was cloud cover(C).

Two non-linear models were tested based on Eq. (3). After finding out parameters, the equation was rearranged like Eq. (7). Because the fact that parameters to be determined appears in both denominator and the numerator of Eq. (7) caused an instability problems in the statistical analysis (SAS 9.1.3, SAS Institute Inc., USA). Therefore, for the non-linear model, $I_{s c}$ in Eq. (3) were used as the dependent variable in the parameter determination. And the order of functions $f_{1}\left(A M_{a}\right)$ and $f_{2}(A O I)$ were assumed $4^{\text {th }}$ and $5^{\text {th }}$, respectively(King et al., 2003). Table 1 summarize the forms of the tested model.

$$
E=\frac{\sqrt{\left\{I_{s c o}+\alpha_{I_{c o}}\left(T_{a}-T_{o}\right)\right\}^{2}+2\left(e^{a}+\frac{\Delta T}{E_{o}}\right) \frac{I_{s c}}{f_{1} f_{2}}}-\left\{I_{s c o}+\alpha_{I_{s c}}\left(T_{a}-T_{o}\right)\right\}}{\frac{1}{E_{o}}\left(e^{a}+\frac{\Delta T}{E_{o}}\right)}
$$

In determining the coefficients of the non-linear model, the MARQUARDT algorithm in the SAS was used instead of NEWTON because the correlation coefficients between parameters were high. The ranges of empirical coefficients for a and temperature difference $(\Delta T)$ were $-1 \sim-4$ and $0 \sim 4{ }^{\circ} \mathrm{C}$, respectively.

Daily collected data were divided into 2 randomly chosen data sets (47 days data and 20 days data) for development and evaluation of models. The coefficient of determination $\left(R^{2}\right)$ and the pseudo $R^{2}$ in Eq. (8) were used for evaluation of the linear regression model and a non-linear regression model repectively, because $R^{2}$ is not usually used for non-linear regression (UCLA, 2011).

$$
\text { Pseudo } R^{2}=1-S S(\text { Residual }) / S S(\text { CorrectedTotal })
$$

The size of the root mean square error, RMSE, was used to evaluate the accuracy of the proposed models to determine the best model.

\section{Results}

\section{Solar radiation pattern}

Figure 3 shows changes of solar radiation and ambient temperature from $14^{\text {th }}$ April 2011 to $20^{\text {th }}$ June 2011. The data on $12^{\text {th }}$ May were considered error and excluded because it was greater than the extraterrestrial solar radiation.

The ranges of solar radiation, ambient temperature and short-circuit current within the test period at the test site were $0 \sim 1,276 \mathrm{~W} / \mathrm{m}^{2}, 4.3 \sim 36.7^{\circ} \mathrm{C}$ and $0 \sim 0.672 \mathrm{~A}$, respectively. The calculated ranges of AOI and $A M_{a}$ were 0.241 1.571 rad and 1.026 3331, respectively.

\section{Regression models}

\begin{tabular}{|c|c|c|c|c|}
\hline Model No. & Type & $\begin{array}{l}\text { Dependent } \\
\text { Variable }\end{array}$ & $\begin{array}{l}\text { Independent variables or } \\
\text { coefficients to be determined }\end{array}$ & $\begin{array}{c}\text { Number of coefficients } \\
\text { to be determined }\end{array}$ \\
\hline 1 & \multirow{2}{*}{ linear } & \multirow{2}{*}{$E$} & $I_{s c}, \cos (A O I), C$ & 3 \\
\hline 2 & & & $I_{s c}, T_{a}, I_{s c} \times T_{a}, \cos (A O I)$ & 4 \\
\hline 3 & non-linear & $I_{S C}$ & coeff. of $f_{1}\left(A M_{a}\right)$, coeff. of $f_{2}(A O I), \Delta T, a$ & 13 \\
\hline
\end{tabular}

Table 2 shows the results of linear regression analysis. The $R^{2}$ values of both models were over 0.95 and it showed significant relations for all coefficients $(\mathrm{P}<$ 0.001).

\section{Table 1. Regression models for estimating solar radiation}




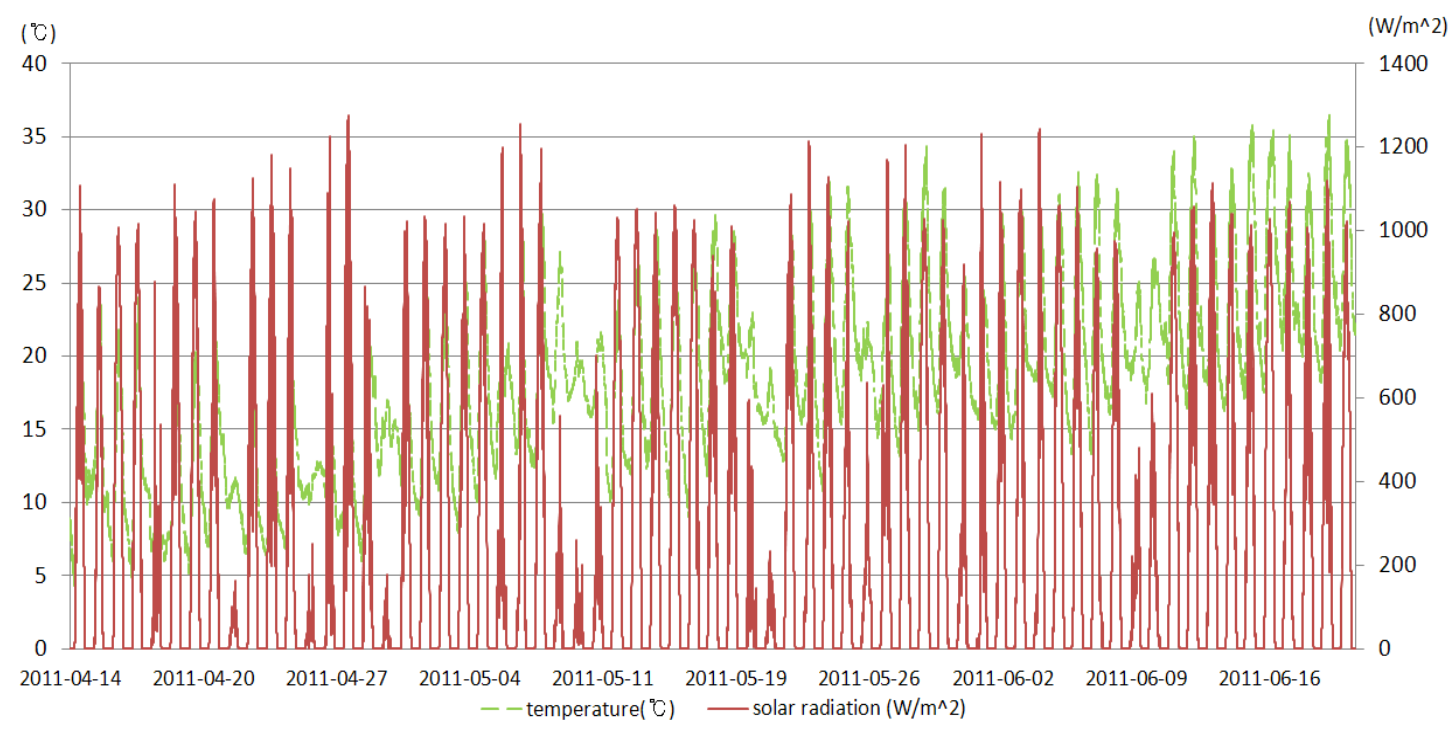

Figure 3. Changes of solar radiation and temperature from $14^{\text {th }}$ April to $20^{\text {th }}$ June in 2011 .

\section{Table 2. Result of linear regression analysis}

\begin{tabular}{cccc} 
Model No. & $R^{2}$ & $\mathrm{~F}$ & Model Equation \\
\hline 1 & 0.957 & $499038^{* *}$ & $E=37.696+1599.294 I_{s c}+134.702 \cos (A O I)-6.146 C$ \\
2 & 0.953 & $342957^{* *}$ & $E=-20.792+1.537 T_{a}+1788.522 I_{s c}+92.769 \cos (A O I)-4.303 T_{a} I_{s c}$ \\
\hline
\end{tabular}

Table 3. Result of non-linear regression analysis

\begin{tabular}{|c|c|c|c|}
\hline $\begin{array}{c}\text { Model } \\
\text { No. }\end{array}$ & $\begin{array}{c}\text { Pseudo } \\
R^{2}\end{array}$ & $\mathrm{~F}$ & Model Equation \\
\hline & & & $I_{s c}=\frac{E}{1000} f_{1}\left(A M_{a}\right) f_{2}(A O I)\left(0.67+0.05\left(E\left(e^{a}+\frac{\Delta T}{1000}\right)+T_{a}-25\right)\right)$ \\
\hline 3 & 0.870 & $63354.1^{* *}$ & $\begin{aligned} & f_{1}\left(A M_{a}\right)= 1.76 E-8 A M_{a}^{4}-0.9 E-4 A M_{a}^{3}+0.09 A M_{a}^{2} \\
&-0.504 A M_{a}+1 \\
& f_{2}(A O I)=-0.441 A O I^{5}-0.244 A O I^{4}+1.048 A O I^{3}+1.339 A O I^{2} \\
&-1.7 A O I+1 \\
& a=-4.2 \\
& \Delta T=3\end{aligned}$ \\
\hline
\end{tabular}

Table 4. Accuracy of the regression models

\begin{tabular}{cccc} 
Model No. & 1 & 2 & 3 \\
RMSE & $66.671 \mathrm{~W} / \mathrm{m}^{2}$ & $69.038 \mathrm{~W} / \mathrm{m}^{2}$ & $214.349 \mathrm{~W} / \mathrm{m}^{2}$ \\
\hline
\end{tabular}

Table 3 shows the results of the non-linear regression. The value of pseudo $R^{2}$ calculated using Eq. (8) was 0.870 . Although $R^{2}$ and pseudo $R^{2}$ could not be compared directly, the value is lower than $R^{2}$ of the linear models.

\section{Evaluations of the models}

Table 4 shows the RMSE values of the developed models. The linear models showed acceptable accuracy for the greenhouse control. The minimum RMSE of 66.671
$\mathrm{W} / \mathrm{m}^{2}$ corresponds to $5.36 \%$ of the maximum solar radiation in the greenhouse. Solar radiation fluctuates quickly with the cloud cover. So, greenhouse environment control systems use the time average of solar radiation. If a greenhouse environment system controls the supplementary lighting or $\mathrm{CO}_{2}$ concentration based on 10 minutes average or longer, then RMSEs of the linear model judged to be acceptable but not sufficient. However some applications (Seshu and Cady, 1983; Roh and Lee, 1996) 


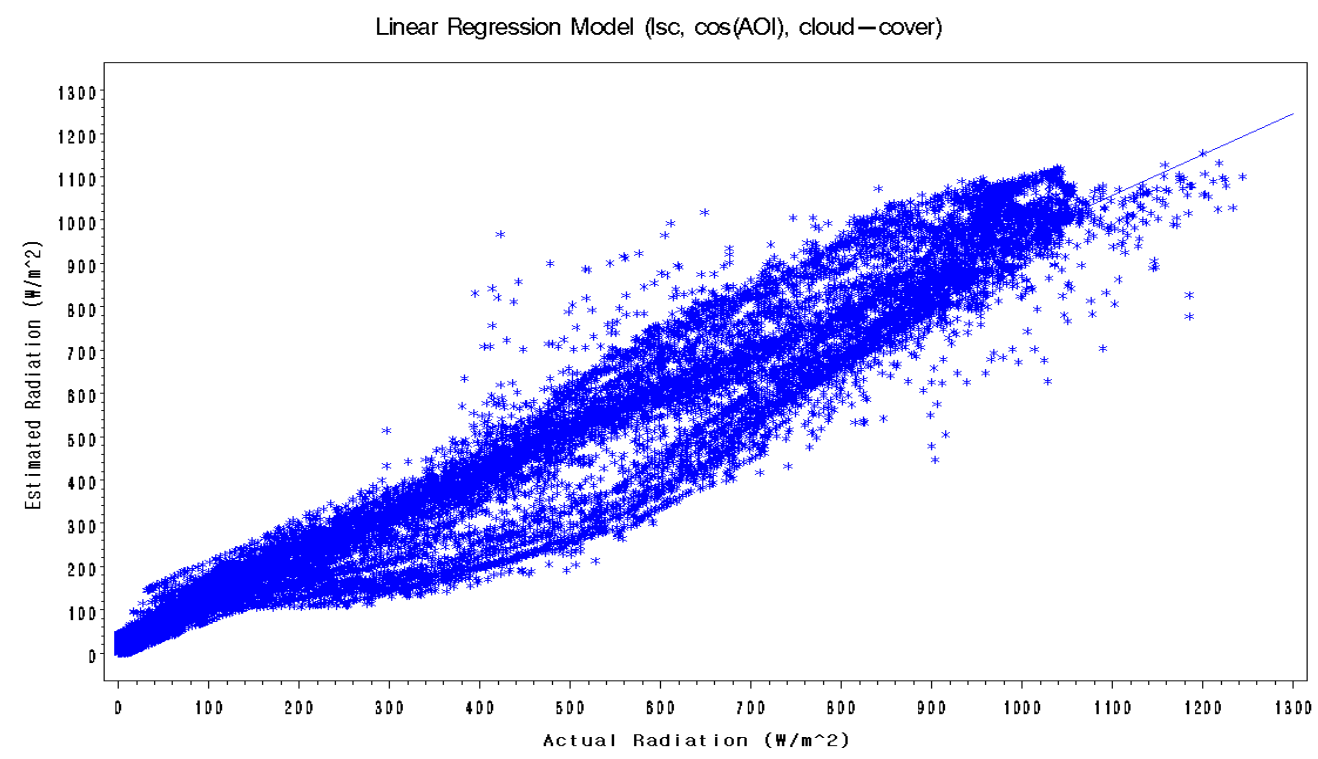

Figure 4. Comparison between actual radiation and estimated radiation using the model 1 .

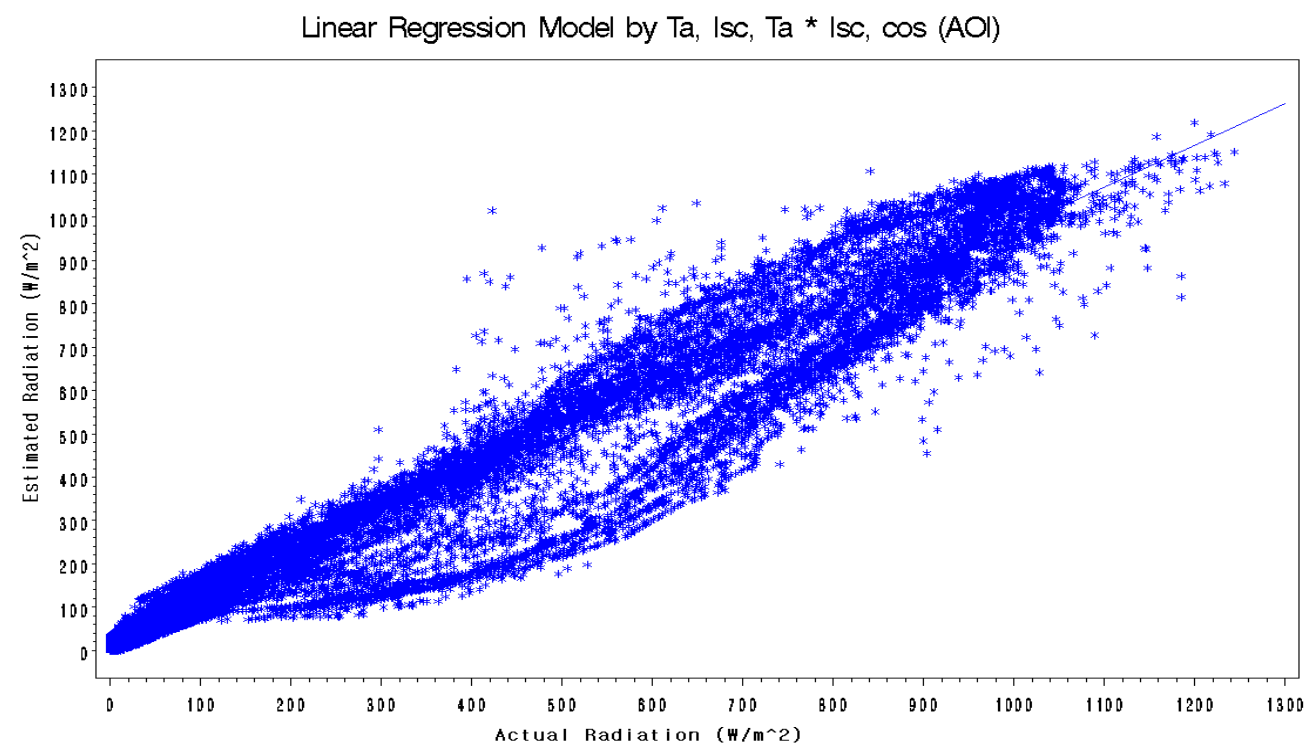

Figure 5. Comparison between actual radiation and estimated radiation using the model 2 .

where accumulated solar radiation is necessary, the developed model is judged to be sufficiently accurate. However, the non-linear model showed large RMSE of $247.365 \mathrm{~W} / \mathrm{m}^{2}$ (17.23\% of the daily maximum solar radiation) and judged to be inacceptable.

The evaluation data sets and the predicted values by the linear regression models were shown in Figure 4 and Figure 5. Both figures showed a distribution pattern of an oval-shape but did not show a noticeable difference even if the RMSEs were different.

Figure 5 shows measured radiation by the pyranometer and estimated by the model 1 on $27^{\text {th }}$ April when the maximum difference $\left(-545.42 \mathrm{~W} / \mathrm{m}^{2}\right)$ between actual and estimated radiation was observed. And the difference increases as radiation changes rapidly. Especially, at $13: 22$, the radiation data from the pyranometer changed $1,151 \mathrm{~W} / \mathrm{m}^{2}$ to $423 \mathrm{~W} / \mathrm{m}^{2}$ suddenly but the estimated radiation changed $1,004 \mathrm{~W} / \mathrm{m}^{2}$ to $968 \mathrm{~W} / \mathrm{m}^{2}$. In other words, the developed experiment set and the solar radiation model could not follow the sudden changes of the solar radiation. The difference fluctuated largely during 9:30 to 11:30 when the actual radiation fluctuate 


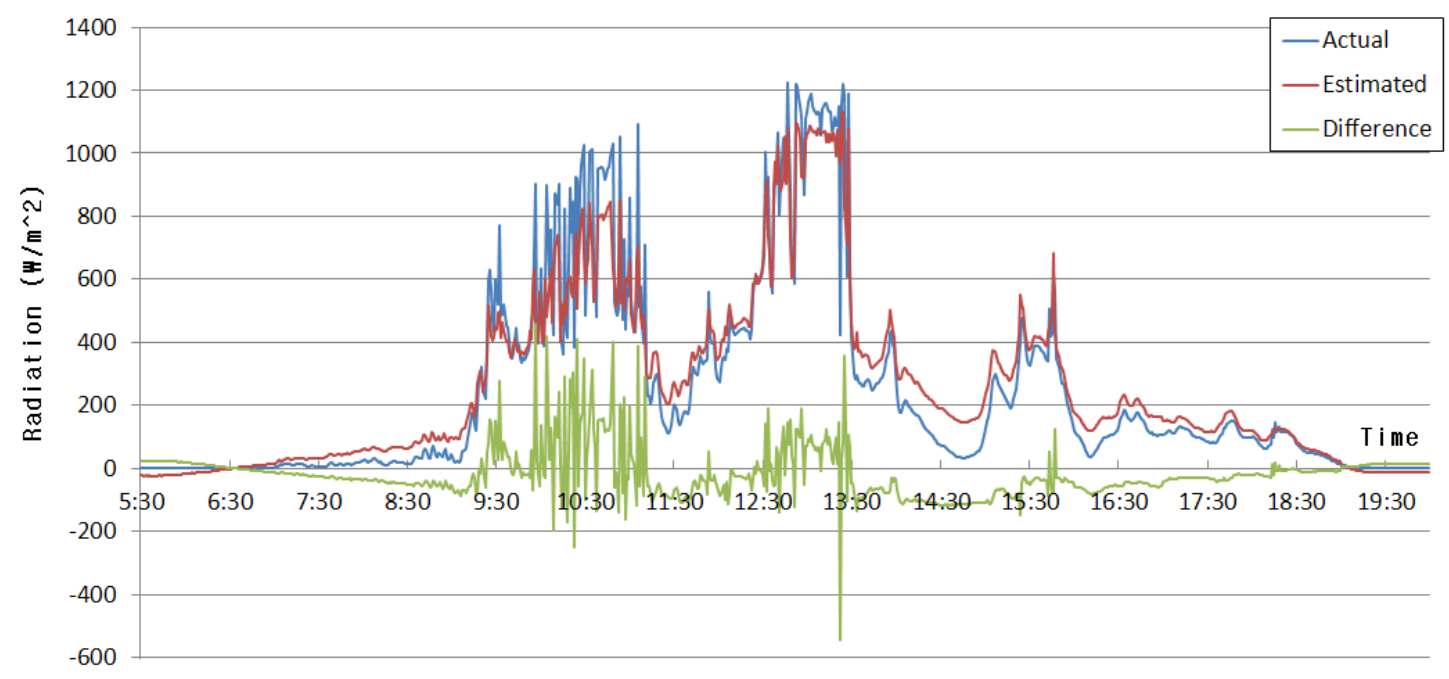

Figure 6. Daily radiation changes on $27^{\text {th }}$ April.

largely. The phenomenon may happen due to the difference of the sensing area. The sensing area of the pyranometer is very small $\left(<1 \mathrm{~mm}^{2}\right)$ while that of the experimental solar module is about $648 \mathrm{~cm}^{2}$. The difference of the sensing area could cause a damping effect or an averaging effect.

Figure 6 compares accumulated actual solar radiation and accumulated estimated solar radiation of model 1. The green line shows ratio of the difference between accumulated actual and estimated solar radiation to daily maximum of accumulated actual solar radiation. Although the maximum ratio is over $24.9 \%$, the average ratio is $3.88 \%$ which is lower than the RMSE ratio for direct use. So the developed model 1 is better for the accumulated solar radiation applications. But it shows over estimated value on cloudy days such as $18^{\text {th }}$ April, $27^{\text {th }}$ April and $6^{\text {th }}$ May. It could has a drawback for control of supplement light.

Although the model 1 showed better accuracy than the model 2, it requires data on the cloud cover which could not measure directly. So the model 2 can be an alternative when the cloud cover data is not available. The model 1 is recommended for a server system which integrates the sensing data and the cloud data from the Internet.

\section{Conclusion}

The use of pyranometer has been increasing in the remote greenhouse control but high cost of the sensor acted as a limiting factor in the use integrated envir- onment sensor to farmers. This study was to develop a low cost solar radiation sensor with reasonable accuracy for the environment control in greenhouses using a solar module. Using experimental data, three statistical models for estimating solar radiation using short-circuit current of a solar module, cloud cover, ambient temperature, angle of incidence and airmass were developed and evaluated.

Main conclusions are as follows:

(1) Two linear regression models showed good predictability $\left(R^{2}>0.95\right)$. The RMSE values evaluated were $66.671 \mathrm{~W} / \mathrm{m}^{2}$ and $69.038 \mathrm{~W} / \mathrm{m}^{2}$.

(2) A non-linear regression model was developed using theoretical equation. The pseudo $R^{2}$ of the non-linear regression model (0.870) was not good compared to the linear models. And the RMSE value was also worse than the linear models.

(3) The linear model using short-circuit current, cloud cover, ambient temperature was accurate enough to measure the accumulated solar radiation applications, but insufficient to measure the real time solar radiation.

(4) The model with cloud cover was better than that without cloud cover but not appropriate for the place where Internet is not available because the cloud cover could not be measured directly. Therefore the model without cloud cover, even if it has a little lower accuracy is good for the remote place. 


\section{Conflict of Interest}

No potential conflict of interest relevant to this article was reported.

\section{Acknowledgments}

This Study was supported by Technology Development Program for Agriculture and Forestry, Ministry for Food, Agriculture, Forestry and Fisheries, Republic of Korea.

\section{References}

Casadesús, J., M. Mata, J. Marsal and J. Girona. 2011. Automated irrigation of apple trees based on measurements of light interception by the canopy. Biosystems Engineering 108(3):220-226.

El-Shobokshy, M. S. and F. M. Hussein. 1993. Effect of dust with different physical properties on the performance of photovoltaic cells. Solar Energy 51(6):505-511.

Gul, M. S., T. Muneer and H. D. Kambezidis. 1998. Models for obtaining solar radiation from other meteorological data. Solar Energy 64(1-3):99-108.

Kasten, F. and G. Czeplak. 1980. Solar and terrestrial radiation dependent on the amount and type of cloud. Solar Energy 24(2):177-189.

Kerr, J. P., G. W. Thurtell and C. B. Tanner. 1967. Integrating pyranometer for climatological observer stations and mesoscale networks. Journal of Applied Meteorology 688-694.

Kim, Y., R. G. Evans and W. M. Iversen. 2008. Remote sensing and control of an irrigation system using a distributed wireless sensor network. IEEE Transactions on Instrumentation and Measurement 57(7):1379-1387.

King, D. L. 1997. Photovoltaic module and array performance characterization methods for all system operating conditions. AIP Conference Proceedings 394(1):347-368.

King, D. L., W. E. Boyson and J. A. Kratochvil. 2003. Photovoltaic array performance model. Albuquerque, NM: Sandia National Labotories.

King, D. L. and D. R. Myers. 1997. Silicon-photodiode pyranometers: operational characteristics, historical experiences, and new calibration procedures. Photovoltaic Specialists Conference. Piscataway, NJ: IEEE.

Kim, T. S. and I. J. Jang. 2007. Development of a Remote Controlled Weeder Driven by Solar Battery Power. Journal of Biosystems Engineering 32(2):91-96.
Klaring, H. P., C. Hauschild, A. Heibner and B. Bar-Yosef. 2007. Model-based control of $\mathrm{CO}_{2}$ concentration in greenhouses at ambient levels increases cucumber yield. Agricultural and Forest Meteorology 143(3-4): 208-216.

Nam, S. W., W. M. Seo, Y. C. Yoon, S. K. Lee, I. B. Lee, H. W. Lee and B. K. Cho. 2008. Bio-environment control engineering, pp. 72-77. Daegu, Korea: Cheongsol Publication (In Korean).

Marshall, B. and R. Thompson. 1987. A Model of the Influence of Air Temperature and Solar Radiation on the Time to Maturity of Calabrese Brassica oleracea var italica. Annals of Botany 60(5):513-519.

Pan, Z., M. Segal, R. W. Arritt and E. S. Takle. 2004. On the potential change in solar radiation over the US due to increases of atmospheric greenhouse gases. Renewable Energy 29(11):1923-1928.

Parretta, A., A. Sarno and L. R. M. Vicari. 1998. Effects of solar irradiation conditions on the outdoor performance of photovoltaic modules. Optics Communications 153 (1-3):153-163.

Roh, M. Y. and Y. B. Lee. 1996. Control of Amount and Frequency of Irrigation according to Integrated Solar Radiation in Cucumber Substrate Culture. Acta Horticulture 440:332-337.

Schabenberger, 0. 2002. SAS Library - Nonlinear Regression in SAS. UCLA: Academic Technology Services, Statistical Consulting Group.

Seshu, D. V. and F. B. Cady. 1983. Response of Rice to Solar Radiation and Temperature Estimated from International Yield Trials1. Crop Science 24(4):649-654.

Sun, Y., L. Li, P. Schulze Lammers, Q. Zeng, J. Lin and H. Schumann. 2009. A solar-powered wireless cell for dynamically monitoring soil water content. Computers and Electronics in Agriculture 69(1):19-23.

Whillier, A. 1964. Simple, accurate, cheap integrating instrument for measuring solar radiation. Solar Energy 8(4):134-136.

Willits, D. H., T. K. Karnoski and W. F. McClure. 1980. A microprocessor-based control system for greenhouse research: Part I hardware. Transactions of the ASABE 23(3):688-0692.

Yoo, H.-C., K.-H. Lee and S.-H. Park. 2008. Analysis of Data and Calculation of Global Solar Radiation based on Cloud Data for Major Cities in Korea. Journal of the Korean Solar Energy Society 28(4):17-24 (In Korean).

Yuehua, H., W. Lei and Z. Jie. 2010. Research of fuzzy control system about greenhouse supplement light lamps based on single-chip microcomputer. Intelligent Control and Automation (WCICA) 8th World Congress. 